\title{
Antinociceptive and Anti-Inflammatory Properties of Daucus carota Seeds Extract
}

\author{
Mani Vasudevan,* Kumar Kishore Gunnam, and Milind Parle \\ Pharmacology Division, Department of Pharmaceutical Sciences, Guru Jambheshwar University of Science and Technology, Hisar, \\ (Haryana) -125 001, India
}

(Received June 7, 2006; Accepted July 25, 2006)

\begin{abstract}
The ethanolic extract of Daucus carota seeds (DCE) was investigated for anti-inflammatory and analgesic activity at the doses [per oral (p.o.)] of 100, 200 and $400 \mathrm{mg} / \mathrm{kg}$ body weight. For evaluation of inflammation carrageenan-, histamine- and serotonin-induced paw edema served as acute models and formaldehyde-induced arthritis served as a chronic model in rats. The acetic acid-induced writhing response and formalin-induced paw licking time in the early and late phases of mice were used to assess analgesic activity. The higher doses of DCE (200 and $400 \mathrm{mg} / \mathrm{kg}$, p.o.) were inhibiting carrageenan, histamine and serotonin-induced paw edema as well as formaldehyde-induced arthritis successfully. In addition, DCE (200 and $400 \mathrm{mg} / \mathrm{kg}$, p.o.) significantly attenuated the writhing responses induced by an intraperitoneal injection of acetic acid and late phase of pain response induced by an subplantar injection of formalin in mice.
\end{abstract}

Key words_ Daucus carota, antinociceptive, anti-inflammatory, paw edema, writhing

\section{INTRODUCTION}

Inflammation or phlogosis is a pathophysiological response of living tissue to injuries that leads to the local accumulation of plasmatic fluid and blood cells. Although it is a defense mechanism, the complex events and mediators involved in the inflammatory reaction can be induced, maintain or aggravate many diseases. ${ }^{1)}$ However, studies have been continuing on inflammatory disease and the side effects of the currently available anti-inflammatory drugs pose a major problem during their clinical use. ${ }^{2)}$ Therefore, development of newer and more anti-inflammatory drugs with lesser side effects is necessary.

Daucus carota Linn. commonly known as "Carrot" belongs to the family Apiaceae (Umbelliferae) and is cultivated almost all over the world as a useful vegetable. Carrot is widely consumed as an aphrodisiac and nervine tonic and its scraped root is used as a local stimulant for indolent ulcers. ${ }^{3)}$ The plant has undergone extensive phytochemical studies and a large number of active ingredients have been iso-

*To whom correspondence should be addressed: Pharmacology Division, Department of Pharmaceutical Sciences, Guru Jambheshwar University of Science and Technology, Hisar, (Haryana) -125 001, India. Tel.: +91-9416139727; Fax: +911662-276240; E-mail: vasumpharmacol@yahoo.co.uk lated. These include volatile oils, steroids, triterpenes, carbohydrates, glycerides, tannins, flavonoids, amino acid, carotene and hydrocarotene. ${ }^{4-6)}$ Pharmacological studies showed that Daucus carota seeds (DCE) exhibit antifertility properties. ${ }^{7,8)}$ The crude extract of root of the plant has been found to be hypoglycemic ${ }^{9)}$ and hepatoprotective. ${ }^{10)}$ Cholinergic activity was also found in water-soluble fraction of the alcoholic extract of seeds. ${ }^{11)}$ Different parts of this plant are used in Indian systems of medicine for the treatment of a broad spectrum of aliments including kidney dysfunction, asthma, dropsy, inflammation, leprosy and worm troubles. ${ }^{12,13)}$ Whether these claims are valid is a subject of great interest and should be probed scientifically. With this aim we carried out an investigation of this plant's potential as an anti-inflammatory and analgesic in rodents.

\section{MATERIALS AND METHODS}

Plant Materials — The seeds of Daucus carota were obtained from local market of Hisar, Haryana (India) in the month of January 2005, which were taxonomically identified and authenticated by The Head, Department of Plant Breeding, Chaudhary Charan Singh Agricultural University, Hisar, 
Haryana (India). A voucher specimen (GJU/ PHARM/09/2005) has been preserved at Pharmacology Division of Department of Pharmaceutical Sciences, G. J. University, Hisar, India for ready reference.

Preparation of the Extract - Collected seeds were powdered in hand grinder and defatted with petroleum ether (b.p. $60-80^{\circ} \mathrm{C}$ ). The defatted seeds $(2 \mathrm{~kg})$ were extracted with $95 \%$ ethanol using a soxhlet extractor, at room temperature. After exhaustive extraction, the ethanolic extract was filtered and concentrated by distillation process. A brownishgreen colored residue was obtained (yield 8.4\% w/ w), which was kept in a desiccator. This ethanolic extract of DCE was used for further experiments.

Animals - All the experiments were carried out using male, Swiss Albino mice (25-30 g) and Wistar rats $(150-200 \mathrm{~g})$ procured from the disease-free small animal house of CCS Haryana Agricultural University, Hisar (Haryana, India). The animals had free access to food and water, and they were housed in a natural (12 hr each) light-dark cycle. Food given to animals consisted of wheat flour kneaded with water and mixed with a small amount of refined vegetable oil. The animals were acclimatized for at least 5 days to the laboratory conditions before doing experiments. The experimental protocol was approved by the Institutional Animal Ethics Committee (IAEC) and the care of laboratory animals was taken as per the guidance of committee for the purpose of control and supervision on experiments on animals (CPCSEA), Ministry of Forests and Environment, Government of India (registration number 0436).

Drugs and Chemicals — The drugs and fine chemicals were purchased from Sigma-Aldrich, U.S.A. All other chemicals and solvents were obtained from local firms (India) and were of highest pure and analytical grade.

Vehicle — Plant extract (DCE), indomethacin and aspirin were suspended in $0.5 \% \mathrm{w} / \mathrm{v}$ carboxymethylcellulose sodium (CMC) and administered orally to animals. Carrageenan, histamine, serotonin, formaldehyde, acetic acid and formalin diluted separately in normal saline and injected.

Acute Toxicity Studies — Acute toxicity studies were performed according to organization for economic co-operation and development (OECD/ OCDE) guidelines. ${ }^{14)}$ Male Swiss mice selected by random sampling technique were employed in this study. The animals were fasted for $4 \mathrm{hr}$ with free access to water only. DCE was administered orally at a dose of $5 \mathrm{mg} / \mathrm{kg}$ initially and mortality if any was observed for 3 days. If mortality was observed in two out of three animals, then the dose administered was considered as toxic dose. However, if the mortality was observed in only one animal out of three animals then the same dose was repeated again to confirm the toxic effect. If no mortality was observed, then only higher $(50,300$, and $2000 \mathrm{mg} / \mathrm{kg}$ ) doses of DCE were employed for further toxicity studies.

Acute Anti-Inflammatory Studies — Carrageenan, histamine and serotonin induced paw edema models were used for evaluating potential of DCE on inflammation. For each model, rats were divided in five groups $(n=6)$. DCE $(100,200$, and $400 \mathrm{mg} /$ $\mathrm{kg})$ and indomethacin $(10 \mathrm{mg} / \mathrm{kg})$ were administered orally one hour before the subplantar injection of edematogenic agent. The control groups of animals were received vehicle $(1 \mathrm{ml} / \mathrm{kg})$ orally. A digital vernier caliper (Model 2061, Mututoyo Digimatic Caliper, Japan) used for measuring paw thickness (mm) of rats. ${ }^{15,16)}$ Edema $(\Delta \mathrm{T})$ was calculated as follows

$$
\Delta \mathrm{T}=\mathrm{T}_{\mathrm{t}}-\mathrm{T}_{0}
$$

Where $T_{t}$ is the right hind paw thickness $(\mathrm{mm})$ at time ' $t$ ', $T_{0}$ is hind paw thickness $(\mathrm{mm})$ before subplantar injection.

Carrageenan Induced Edema in Rats — In this method, acute inflammation was produced by the subplantar administration of $0.1 \mathrm{ml}$ of $1 \% \mathrm{w} / \mathrm{v}$ carrageenan in the right paw of the rat. The thickness $(\mathrm{mm})$ of the paw was measured immediately and at $1,2,3$, and $4 \mathrm{hr}$ intervals after the injection of the carrageenan. ${ }^{15,17-20)}$

Histamine and Serotonin Induced Edema in Rats — Edema in rats was induced by injecting $0.1 \mathrm{ml}$ of $0.1 \% \mathrm{w} / \mathrm{v}$ histamine or $0.2 \% \mathrm{w} / \mathrm{v}$ serotonin in subplantar region of the right hind paw. The thickness (mm) of the paw was measured immediately and at 1,2, 3, and $4 \mathrm{hr}$ intervals after the administration of the histamine or serotonin. ${ }^{17,21)}$

Formaldehyde Induced Arthritis in Rats — Experimental arthritis was induced in male rats according to the method described by Selye. ${ }^{22)}$ The animals were divided into three groups of six rats each. A subplantar injection of $0.1 \mathrm{ml}$ of $2 \% \mathrm{v} / \mathrm{v}$ formaldehyde was administered to the right hind paw on the first and third day of the experiment. Plant extract $(400 \mathrm{mg} / \mathrm{kg})$ or indomethacin $(10 \mathrm{mg} / \mathrm{kg})$ or vehicle $(0.5 \% \mathrm{w} / \mathrm{v} \mathrm{CMC})$ was administered orally once daily for 10 days. The paw thickness $(\mathrm{mm})$ of each group was measured for 10 days using a digital vernier caliper (Model 2061, Mututoyo Digimatic 
Caliper, Japan). On day 3 of the treatment, the paw thickness $(\mathrm{mm})$ was measured before the injection of formaldehyde. ${ }^{23)}$ Edema $(\Delta \mathrm{T})$ was calculated as follows:

$$
\Delta \mathrm{T}=\mathrm{T}_{\mathrm{d}}-\mathrm{T}_{0}
$$

Where $T_{d}$ is the right hind paw thickness (mm) on day ' $\mathrm{d}$ ', $\mathrm{T}_{0}$ is hind paw thickness $(\mathrm{mm})$ before subplantar injection.

\section{Acetic Acid-Induced Writhing Response in} Mice - Analgesic activity was evaluated on the acetic acid-induced writhing according to Koster $e t$ $a l .{ }^{24)}$ Male albino mice were divided in to five groups of six animals each. The animals were pretreated with DCE $(100,200$, and $400 \mathrm{mg} / \mathrm{kg}$, p.o.) or aspirin (200 mg/kg, p.o.) used as a standard drug, one hour prior to intraperitoneal injection of $1 \% \mathrm{v} / \mathrm{v}$ acetic acid $(0.1 \mathrm{ml} / 10 \mathrm{~g})$. Five minutes after the intraperitoneal injection of acetic acid, the number of writhing during the following $10 \mathrm{~min}$ was counted. Control mice received drugless $(0.5 \% \mathrm{w} / \mathrm{v} \mathrm{CMC} ; 10 \mathrm{ml} /$ $\mathrm{kg}$ ) vehicle. ${ }^{20,25)}$

Formalin Test — The antinociceptive activity of the drugs was determined by using the formalin test described by Dubuisson and Dennis. ${ }^{26)}$ Male albino mice (overnight fasted, with free access to water) were divided into five groups $(n=6)$. DCE $(100$, 200 , and $400 \mathrm{mg} / \mathrm{kg}$ ) and aspirin $(200 \mathrm{mg} / \mathrm{kg}$, standard drug) were administered orally one hour before formalin injection. Control group received $(10 \mathrm{ml} / \mathrm{kg})$ only drugless vehicle $(0.5 \% \mathrm{w} / \mathrm{v} \mathrm{CMC})$. One hour before testing, the animal was placed in a standard case $\left(30 \times 12, \times 13 \mathrm{~cm}^{3}\right)$ that served as an observation chamber. $20 \mu \mathrm{l}$ of $1.0 \% \mathrm{v} / \mathrm{v}$ formalin injected into dorsal surface of the right hind-paw. The mice were observed for $40 \mathrm{~min}$ after the injection of formalin, and the amount of time spent licking the injected hind-paw was recorded. The first 5 min post formalin injection is known as the early phase and the period between 15 and $40 \mathrm{~min}$ as the late phase. ${ }^{27)}$

Statistical Analysis — All the results were expressed as mean \pm standard error (S.E.). Data was analyzed using one-way analysis of variance test (ANOVA) followed by Dunnett's $t$-test. $p$-values < 0.05 were considered as statistically significant.

\section{RESULTS}

\section{Acute Toxicity Studies}

All the doses $(5,50,300$, and $2000 \mathrm{mg} / \mathrm{kg}$, p.o.) of DCE employed for acute oral toxicity studies were found to be non-toxic. Daucus carota extract did not produce any mortality even at the highest dose ( $2000 \mathrm{mg} / \mathrm{kg}$, p.o.) employed. Three submaximal doses $(100,200$, and $400 \mathrm{mg} / \mathrm{kg}$, p.o.), which were found to be safe in mice were employed for further psychopharmacological and biochemical investigations.

\section{Carrageenan Induced Edema in Rats}

Subplantar injection of carrageenan in rats showed to a time-dependent increase in paw thickness (Fig. 1); this increase was observed at $1 \mathrm{~h}$ and was maximal at $3 \mathrm{hr}$ after administration of carrageenan injection in the vehicle treated groups. However, carrageenan-induced inflammation was significantly $(p<0.001)$ reduced in all phases of the experiment by treatment with DCE 200 and $400 \mathrm{mg} /$ $\mathrm{kg}$ as well as indomethacin. The lower dose of extract $(100 \mathrm{mg} / \mathrm{kg}$, p.o.) did not show any considerable change in paw edema as compared with vehicle treated group (Fig. 1).

\section{Histamine and Serotonin Induced Edema in Rats}

Figures 2 and 3 show the effects of histamine and serotonin induced paw edema in rats. The maximal paw thickness was observed at $1 \mathrm{hr}$ of after subplantar injection in vehicle treated groups of both the models. The animals treated with higher doses of DCE (200 and $400 \mathrm{mg} / \mathrm{kg}$, p.o.) as well as indomethacin $(10 \mathrm{mg} / \mathrm{kg}$, p.o.) produced statistically significant $(p<0.001)$ inhibition of the edema induced by histamine or serotonin in all the phases, when compared to the vehicle treated groups.

\section{Formaldehyde Induced Arthritis in Rats}

Continuous oral treatment (10 days) with plant extract $(400 \mathrm{mg} / \mathrm{kg})$ and indomethacin $(10 \mathrm{mg} / \mathrm{kg})$ remarkably reduced the paw edema induced by formaldehyde in rats. The significant difference $(p<$ 0.001 ) in paw thickness were observed from first day and throughout the period of the experiment as compared with vehicle treated group (Fig. 4).

\section{Acetic Acid-Induced Writhing Response in Mice}

Figure 5 shows the pain behavior of writhing response which was presented as cumulative abdominal stretching response. The treatment of animals with DCE (200 and $400 \mathrm{mg} / \mathrm{kg}$, p.o.) produced a significant $(p<0.001)$ and dose depend inhibition in abdominal writhes produced by acetic acid. The inhibition by DCE ( $400 \mathrm{mg} / \mathrm{kg}$, p.o.) was nearly simi- 


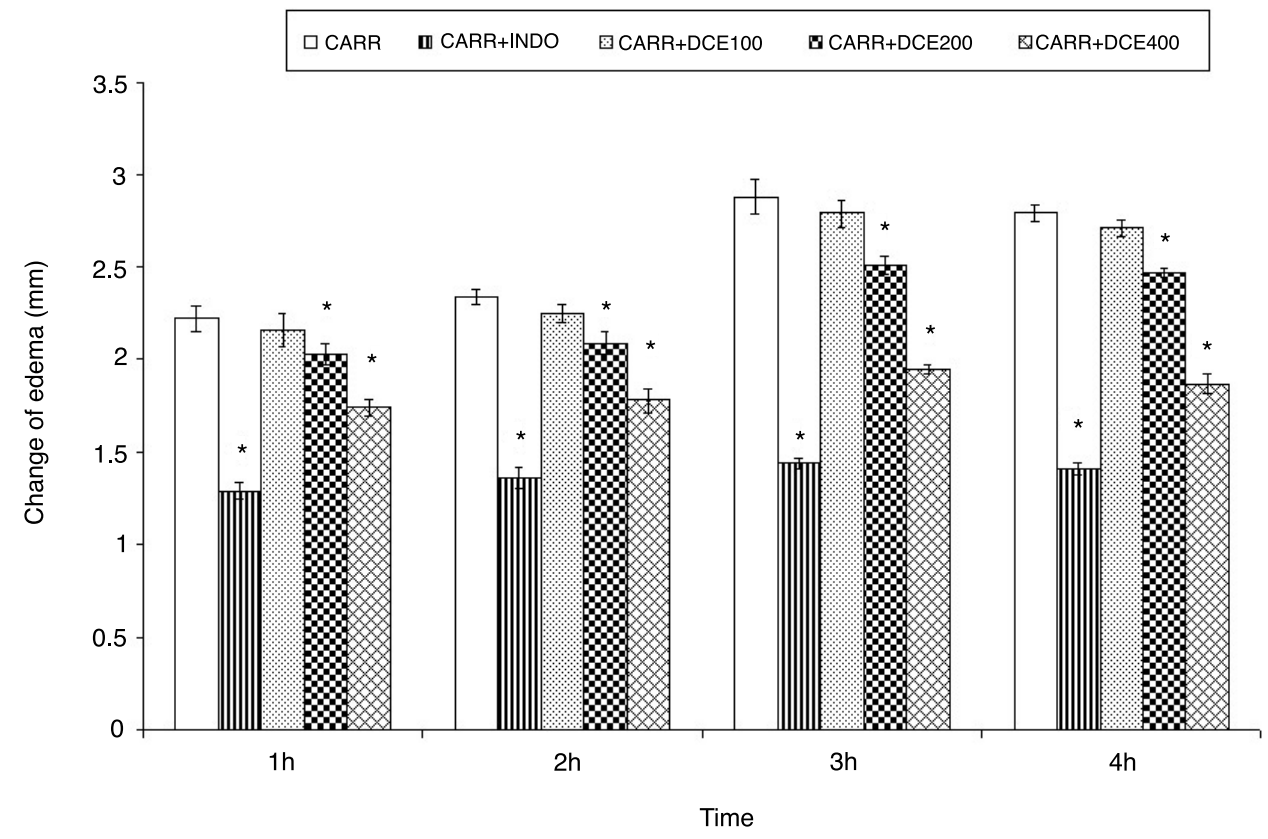

Fig. 1. The Effects of DCE and Indomethacin (INDO) on Rat's Hind Paw Edema Induced by Carrageenan (CARR) Data represented as mean \pm S.E. $(n=6) . * p<0.001$ as compared with the CARR group.

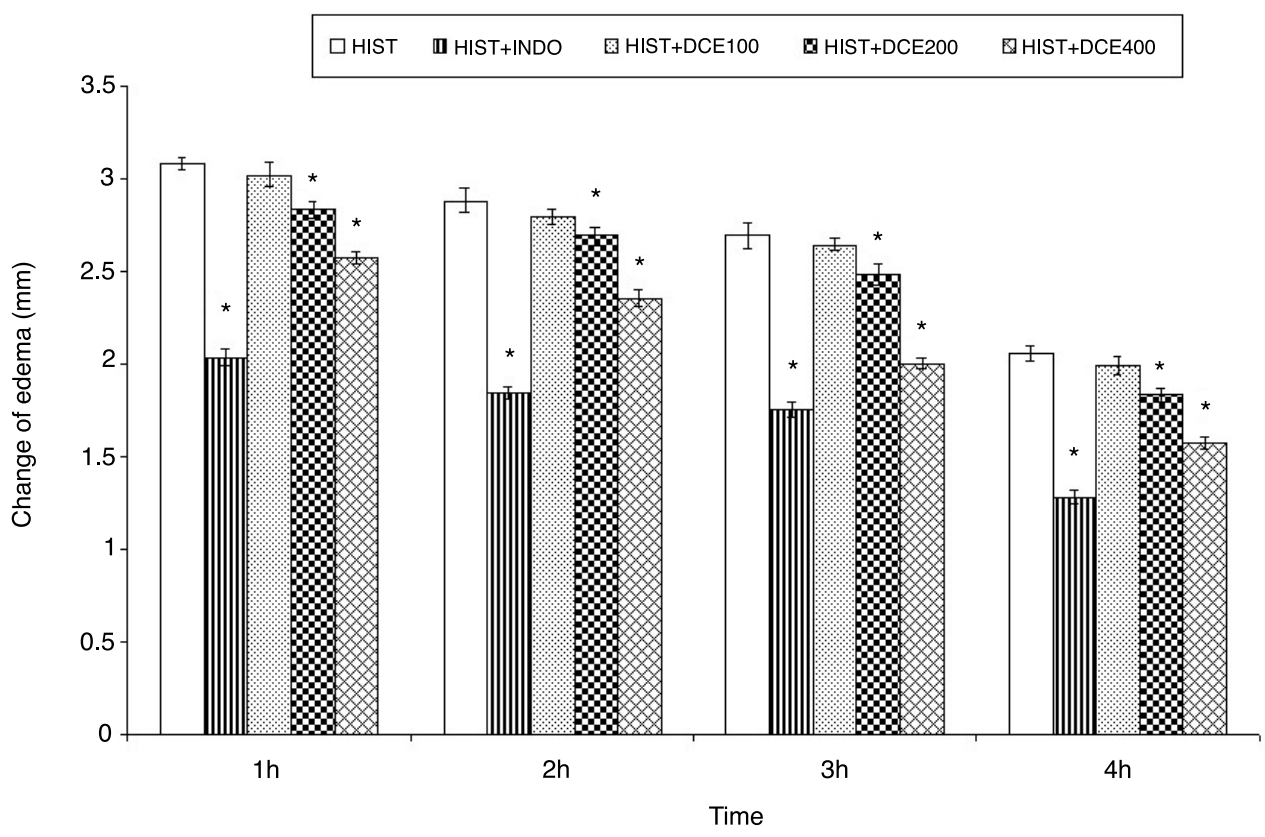

Fig. 2. The Effects of DCE and INDO on Rat's Hind Paw Edema Induced by Histamine (HIST) Data represented as mean \pm S.E. $(n=6) .{ }^{*} p<0.001$ as compared with the HIST group.

lar to that produced by aspirin $(200 \mathrm{mg} / \mathrm{kg}$, p.o.), used as a standard drug.

\section{Formalin-Induced Paw Licking in Mice}

In Fig. 6, it is shown that pretreatment with aspirin or DCE $(100,200$, and $400 \mathrm{mg} / \mathrm{kg}$, p.o.) could not produce any significant changes of paw licking time in the early phase of pain response. However, in the late phase, a dose-dependent and significant $(p<0.001)$ reduction in licking time was observed in mice treated with DCE (200 and $400 \mathrm{mg} / \mathrm{kg}$, p.o.) as well as with aspirin $(200 \mathrm{mg} / \mathrm{kg}$, p.o.). 


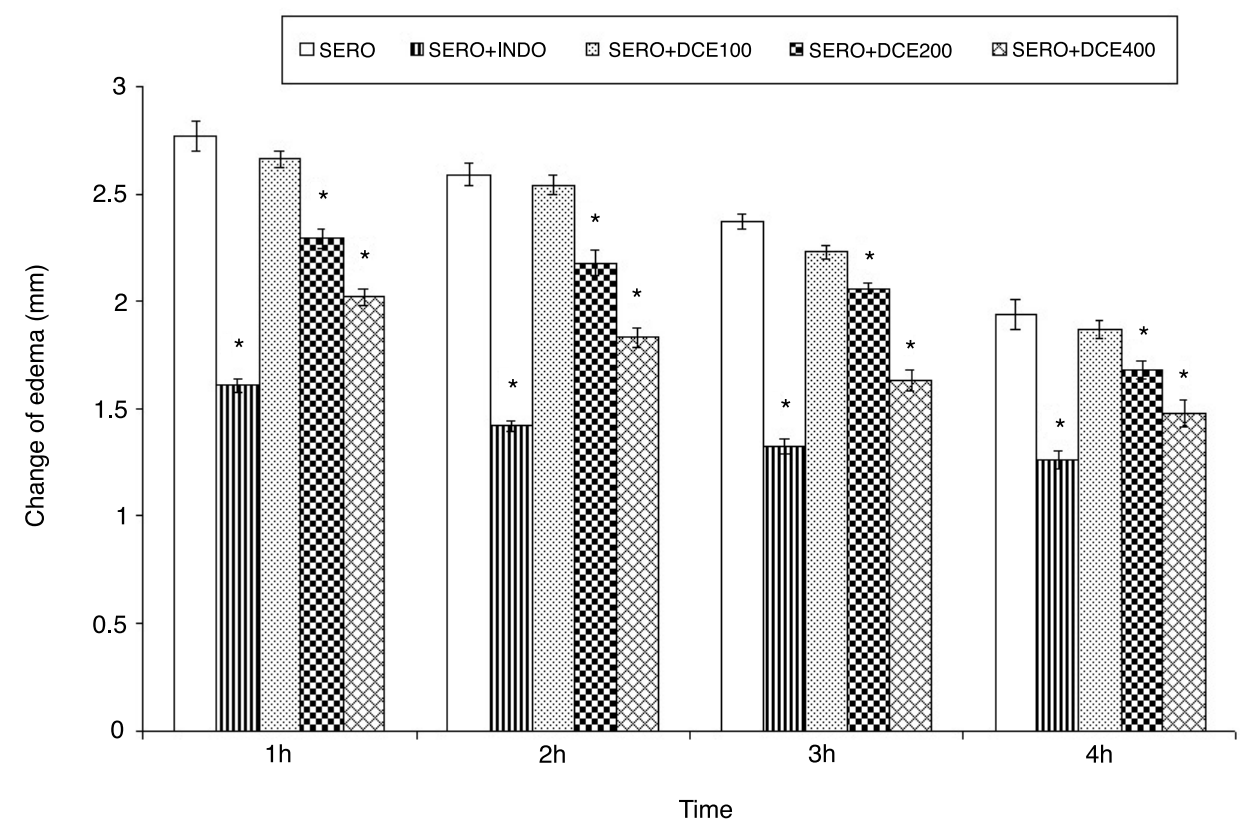

Fig. 3. The Effects of DCE and INDO on Rat's Hind Paw Edema Induced by Serotonin (SERO) Data represented as mean \pm S.E. $(n=6) . * p<0.001$ as compared with the SERO group.

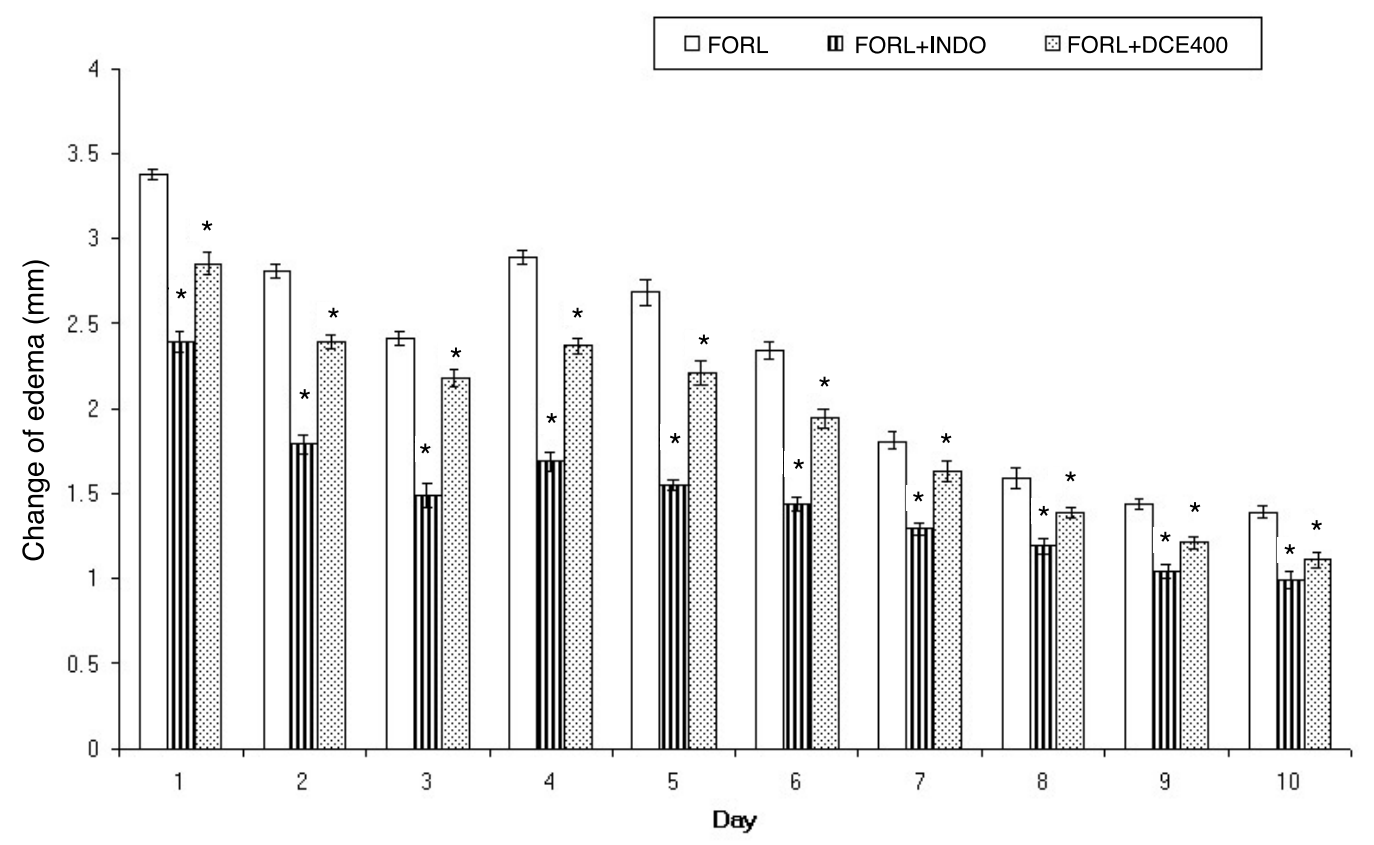

Fig. 4. The Effects of DCE and INDO on Rat's Hind Paw Edema Induced by Formaldehyde (FORL) Data represented as mean \pm S.E. $(n=6){ }^{*} p<0.001$ as compared with the FORL group.

\section{DISCUSSION}

In the present study, the anti-inflammatory activities of the ethanolic extract of DCE has been established in both acute and chronic inflammation models, which were employed. Carrageenan-in- duced rat paw edema is a suitable test for evaluating anti-inflammatory drugs which has frequently been used to assess the anti-edematous effect of natural products. ${ }^{28)}$ Development of edema in the paw of the rat after injection of carrageenan is a biphasic event. ${ }^{29)}$ The initial phase observed during the first 


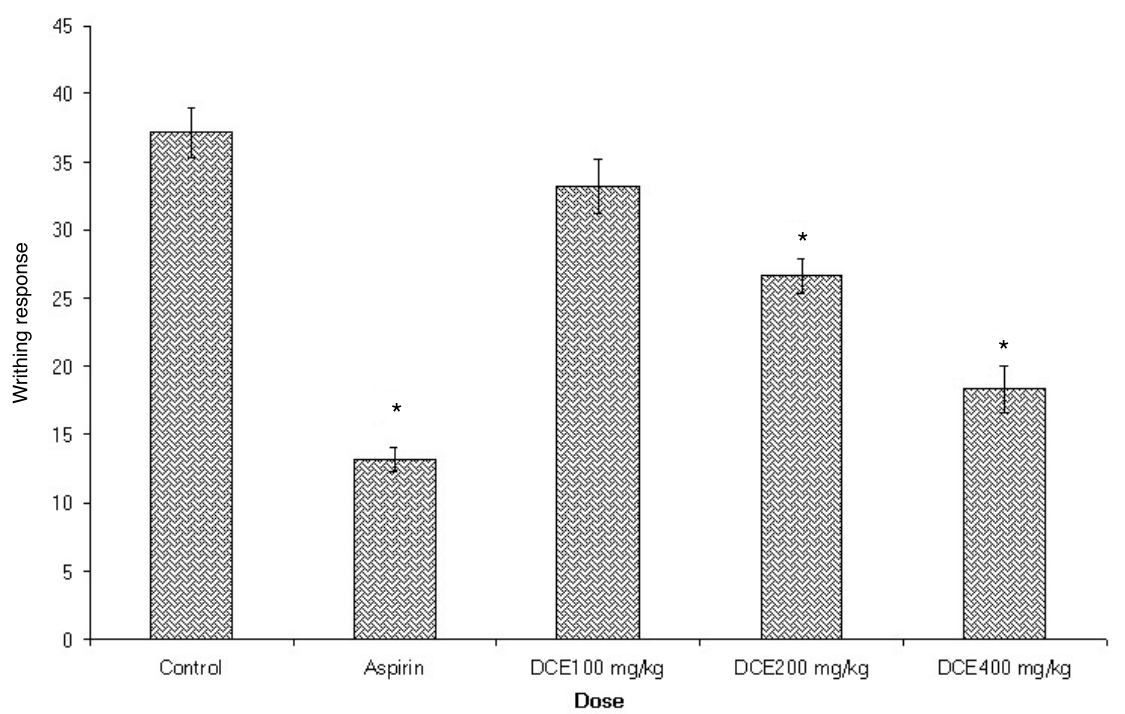

Fig. 5. The Effects of DCE on $1 \% \mathrm{v} / \mathrm{v}$ Acetic Acid-Induced Writhing Response in Mice Data represented as mean \pm S.E. $(n=6) . * p<0.001$ as compared with the control group.

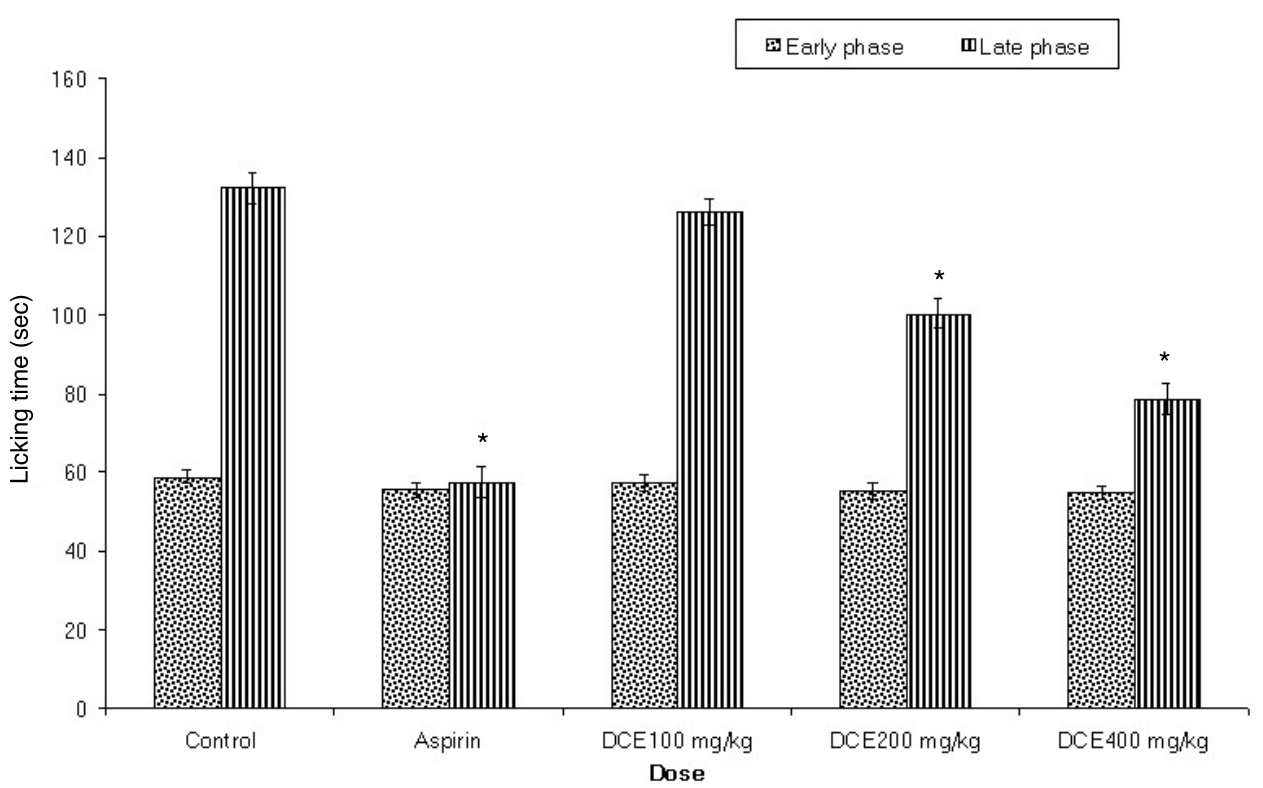

Fig. 6. The Effects of DCE on the Early Phase and Late Phase in $20 \mu \mathrm{l}$ of $1 \% \mathrm{v} / \mathrm{v}$ Formalin Test in Mice Data represented as mean \pm S.E. $(n=6) .{ }^{*} p<0.001$ as compared with the control group.

hour is attributed to the release of histamine and serotonin. ${ }^{30)}$ The second phase of edema is due to the release of prostaglandins, protease and lysosome. ${ }^{29,30)}$ The result of the present study indicates that DCE (200 and $400 \mathrm{mg} / \mathrm{kg}$, p.o.) and indomethacin play a crucial role as protective factors against the carrageenan-induced acute inflammation.

Histamine and serotonin are important inflammation mediators and they are potent vasodilator substances as well as increase the vascular permeability. ${ }^{31-33)}$ This study showed that DCE (200 and
$400 \mathrm{mg} / \mathrm{kg}$, p.o.) also effectively suppressed the edema produced by the histamine and serotonin. It is well known that inhibition of formaldehyde induced pedal edema in rats is one of the most suitable test procedures to screen anti-arthritic and antiinflammatory agents as it closely resembles human arthritis. ${ }^{34)}$ Thus formaldehyde-induced arthritis is a model used for the evolution of an agent with antiinflammatory activity. ${ }^{35)}$ This experiment is associated with probable anti-inflammatory activity. Injection of formaldehyde subcutaneously into hind 
paw of rats produces localized inflammation. DCE ( $400 \mathrm{mg} / \mathrm{Kg}$, p.o.) and indomethacin $(10 \mathrm{mg} / \mathrm{kg}$, p.o.) administered continuously for 10 days successfully inhibited edema induced by formaldehyde.

The writhing induced by chemical substances is due to sensitization of nociceptors by prostaglandins. ${ }^{36,37)}$ The abdominal constriction response induced by acetic acid is a sensitive procedure to establish peripherally acting analgesic. This response is thought to involve local peritoneal receptors. ${ }^{38,39)}$ The treatment of animals with DCE (200 and 400 $\mathrm{mg} / \mathrm{kg}$, p.o.) showed a significant inhibition of the writings which was similar to that of the effect produced by Aspirin (100 mg/kg, p.o.). This result indicates that the analgesic effect of DCE might be mediated by its peripheral effects.

Extract (200 and $400 \mathrm{mg} / \mathrm{kg}$, p.o.) also produced significant inhibition in the late phase of formalin induced pain. The formalin test is a valid and reliable model of nociception and is sensitive for various classes of analgesic drugs. The formalin test produced a distinct biphasic response and different analgesics may act differentially in the early and late phases of this test. Therefore, the test can be used to clarify the possible mechanism of antinociceptive effect of a proposed analgesic. ${ }^{40)}$ Centrally acting drugs such as opioids inhibit both phases equally. ${ }^{41)}$ But peripherally acting drugs such as aspirin, indomethacin and dexamethasone only inhibit the late phase. The late phase seems to be an inflammatory response with inflammatory pain that can be inhibited by anti-inflammatory drugs. ${ }^{20,42,43)}$ The effect of DCE on the late phase of formalin test suggests that its activity may be resulting from its peripheral action, when compared with aspirin activity in this respect.

In conclusion, the data obtained in this study demonstrated that DCE extract might have analgesic and anti-inflammatory activities. Further studies are necessary to elucidate the mechanisms behind its traditional effects.

Acknowledgements Authors owe a deep sense of gratitude to Dr. R. P. Bajpai, Hon'ble Vice Chancellor of Guru Jambheshwar University of Science and Technology, Hisar for his constant encouragement and inspiration. The authors are thankful to Dr. D. N. Mishra, Chairman, Department of Pharmaceutical Sciences, Guru Jambheshwar University of Science and Technology, Hisar for providing infrastructural facilities to carry out this project. We are grateful to Dr. P. K. Kapoor, Scientist In-charge,
Disease free animal house, CCS Haryana Agricultural University, Hisar for continuous supply of animals.

\section{REFERENCES}

1) Sosa, S., Balick, M. J., Arvigo, R., Esposito, R. G., Pizza, C. and Altinier, G. (2002) A screening of the topical anti-inflammatory activity of some central American plants. J. Ethnopharmacol., 8, 211-215.

2) Vane, J. R. and Bolting, R. M. (1995) New insights into the mode of action of anti-inflammatory drugs. Inflammation Res., 44, 1-10.

3) Shastri B. N. (1952) Wealth of India-Raw Materials, CSIR Publication, New Delhi.

4) Mahran, G. H., Kadry, H. A., Isaac, Z. G., Jhabet, C. T., Al-Azizi, M. and El-Oiemy, M. (1991) Investigation of diuretic drug plants. Phytochemical screening and pharmacological evaluation of Anethum graveolens L., Apium graveolens L., Daucus carota L. and Eruca sativa Mill. Phytother. Res., 5, 169-172.

5) Gilani, A. H., Shaheen, F., Shaheen, F., Saeed, S. A., Bibi, S., Irfanullah, Sadiq, M. and Faizi, S. (2000) Hypotensive action of coumarin glycosides from Daucus carota. Phytomedicine, 7, 423-426.

6) Mazzoni, V., Tomi, T. and Casanova, J. (1999) A daucane-type seaquiterpene from Daucus carota seed oil. Flavour Fragr. J., 14, 268-272.

7) Bhatnagar, U. (1995) Postcoital contraceptive effects of a alcoholic extract of Daucus carota Linn. seed in rats. Clin. Drug Invest., 9, 30-36.

8) Majumdar, U. K., Gupta, M. and Patro, V. J. (1998) Studies on antifertility of methanolic extract of Daucus carota Linn. seeds. Indian J. Nat. Prod., 14, 33-37.

9) Neef, H., Declereq, H. N. and Laekemen, G. (1995) Hypoglycemic activity of selected European plats. Phytother. Res., 9, 45-48.

10) Bishayee, A., Sarkar, A. and Chatterjee, M. (1995) Hepatoprotective activity of carrot (Daucus carota L.) against carbon tetrachloride in mouse liver. $J$. Etnopharmacol., 47, 69-74.

11) Gambhir, S. S., Sanyal, A. K., Sen, S. P. and Das, P. K. (1966) Studies on Daucus carota Linn. Part II. Cholinergic activity of the quaternary base isolated from water-soluble fraction of alcoholic extract of seeds. Indian J. Med. Res., 54, 1053-1056.

12) Chopra R. N., Chopra I. C., Handa K. L. and Kapur L. D. (1958) Chopra's Indigenous Drugs of India, U.N. Dhar and Sons Pvt Ltd., Calcutta.

13) Nadkarni, K. M. (1976) Indian Materia Medica, Popular Prokashan, Bombay.

14) Ecobichon, D. J. (1997) The basis of toxicology test- 
ing, CRC Press, New York.

15) Dai, Y., But, P. P., Chan, Y., Matsuda, H. and Kubo, M. (2002) Antipruritic and Antiinflammatory effects of aqueous extract from Si-Wu-Tang. Biol. Pharm. Bull., 25, 1175-1178.

16) Murayama, M., Mori, T., Bendo, H. and Amiya, T. (1991) Studies on the constituents of Aconitum species. IX. The pharmacological properties of pyrotype aconitine alkaloids components of processed aconite powder 'Kako-bushi-matsu': analgesic, antiinflammatory and acute toxic activities. $J$. Ethnopharmacol., 35, 159-164.

17) Winter, C. A., Risley, E. A. and Nuss, G. W. (1962) Carrageenan-induced edema in hind paw of the rat as an assay for anti-inflammatory drugs. Proc. Soc. Exp. Biol. Med., 111, 544-547.

18) Kweifio-Okai, G. (1991) Anti-inflammatory activities of Ghanaian antiarthritic herbal preparation: I. J. Ethnopharmacol., 33, 263-267.

19) Nkeh, B. C., Njamen, D., Wandji, J., Fomum, Z. T., Dongmo, A., Nguelefack, T. B., Wansi, D. and Kamanyi, A. (2003) Anti-inflammatory and analgesic effects of Drypemolundein A, a Sesquiterpene lactone from Drypetes molunduana. Pharm. Biol., 41, 26-30.

20) Young, H., Luo, Y., Cheng, H., Hsieh, W., Liao, J. and Peng, W. (2005) Analgesic and anti-inflammatory activities of [6] - gingerol. J. Ethnopharmacol., 96, 207-210.

21) Suleyman, H., Demirezer, L. O., Kuruuzum, A., Banoglu, Z. N., Gocer, F., Ozbakir, G. and Gepdiremen, A. (1999) Anti-inflammatory effect of the aqueous extract from Rumex patientia L. roots. J. Ethnopharmacol., 65, 141-148.

22) Selye, H. (1949) Further studies concerning the participation of the adrenal cortex in the pathogenesis of arthritis. Brit. Med. J., 2, 1129-1135.

23) Moura, A. C. A., Silva, E. L. F., Fraga, M. C. A., Wanderley, A. G., Pour, A. P. and Maia, M. B. S. (2005) Anti-inflammatory and chronic toxicity study of the leaves of Ageratum conyzoides L. in rats. Phytomedicine, 12, 138-142.

24) Koster, R., Anderson, M. and De-Beer, E. J. (1959) Acetic acid analgesic screen. Fed. Proc. Fed. Am. Soc. Exp. Biol., 18, 418-420.

25) Taber, R. I., Greenhouse, D. D., Rendell, J. K. and Irwin, S. (1969) Agonist and antagonist interactions of opioids on acetic acid-induced abdominal stretching in mice. J. Pharmacol. Exp. Ther., 169, 29-37.

26) Dubuisson, D. and Dennis, S. G. (1977) The formalin test: a quantitative study of the analgesic effects of morphine meperidine, the brain stem stimulation in rats and cats. Pain, 4, 167-174.

27) Yongna, Z., Wantana, R., Pisit, B., Zhongkun, L. and Rongping, Z. (2005) Analgesic and antipyretic activities of the aqueous extract of Urtica macrorrhiza in experimental animals. Fitoterapia, 76, 91-95.

28) Panthong, A., Kanjanapothi, D., Taesotikul, T., Wongcome, T. and Reutrakul, V. (2003) Anti-inflammatory and antipyretic properties of Clerodendrum petasites S. Moore. J. Ethnopharmacol., 85, 151156.

29) Vinegar, R., Schreiber, W. and Hugo, R. (1969) Biphasic development of carrageenan edema in rats. J. Pharmacol. Exp. Ther., 166, 96-103.

30) Crunkhon, P. and Meacock, S. E. R. (1971) Mediators of the inflammation induced in the rat paw by carrageenan. Brit. J. Pharmacol., 42, 392-402.

31) Linardi, A., Costa, S. K. P., DeSilva, G. R. and Antunes, E. (2002) Involvement of kinins, mast cells and sensory neurons in the plasma exudation and paw edema induced by Styphylococcal entrotoxin B in the mouse. Eur. J. Pharmacol., 399, 235-242.

32) Cuman, R. K. N., Bersani-Amadio, C. A. and Fortes, Z. B. (2001) Influence of type 2 diabetes on the inflammatory response in rat. Inflammation Res., $\mathbf{5 0}$, 460-465.

33) Skidmore, I. and Whitehouse, M. (1967) Biochemical properties of anti-inflammatory drugs $\mathrm{X}$ : the inhibition of serotonin formation in vitro and inhibition of the esterase activity of $\alpha$-Chymyotrysin. Biochem. Pharmacol., 16, 737-751.

34) Greenwald, R. A. (1991) Animal models for evolution of arthritic drug. Method. Find. Exp. Clin. Pharmacol., 13, 75-83.

35) Banerjee, S., Sur, T. K., Mandal, S., Das, P. C. and Sikdar, S. (2000) Assessment of the anti-inflammatory effects of Swertia chirata in acute and chronic experimental models in male albino rats. Indian $J$. Pharmacol., 32, 21-24.

36) Perianayagam, J. B., Sharma, S. K., Joseph, A. and Christina, A. J. M. (2004) Evaluation of anti-pyretic and analgesic activity of Emblica officinalis Gaertn. J. Ethnopharmacol., 95, 83-85.

37) Berkenkopf, J. W. and Weichmann, B. M. (1988) Production of prostacyclin in mice following intraperitoneal injection of acetic acid, phenyl benzoquinone and zymosan: its role in the writhing response. Prostag., Leukotr. Ess., 36, 693-709.

38) Hokanson, G. C. (1978) Acetic acid for analgesic screening. J. Nat. Prod., 41, 497-498.

39) Chakraborty, A., Devi, R. K. B., Rita, S., Sharatchandra, K. and Singh, T. I. (2004) Preliminary studies on anti-inflammatory and analgesic activities of Spilanthes acmella in experimental animal models. Indian J. Pharmacol., 36, 148-150.

40) Tjolsen, A., Berge, O. G., Hunskaar, S., Rosland, J. H. and Hole, K. (1992) The formalin test: an evaluation of the method. Pain, 51, 5-17. 
41) Shibata, M., Ohkubo, T., Takahashi, H. and Inoki, R. (1989) Modified formalin test: characteristic biphasic pain response. Pain, 38, 347-352.

42) Hunskaar, S. and Hole, K. (1987) The formalin test in mice: dissociation between inflammatory and non- inflammatory pain. Pain, 30, 103-114.

43) Rosland, J. H., Tjolsen, A., Maehle, B. and Hole, K. (1990) The formalin test in mice: effect of formalin concentration. Pain, 42, 235-242. 